\title{
Tingkat pengetahuan remaja tentang personal hygiene
}

\author{
Wazni Adila ${ }^{1^{*}}$; Margareta Rinjani²; Prala Cinderela ${ }^{3}$ \\ 1,2,3Sekolah Tinggi ilmu Kesehatan Adila Di Kota Bandar lampung, Jl.Soekarno Hatta Baypass Rajabasa \\ Bandar Lampung, 3500 Tlp/Fax (0721) 784370 \\ e-mail: wazniadila@gmail.com ${ }^{1 *}$; margarethrinjani89@gmail.com $^{2}$; prala cinderela@gmail.com ${ }^{3}$
}

\begin{abstract}
Abstrak. Menurut Word Health Organitation (WHO), masa remaja merupakan masa peralihan dari masa anak-anak menuju dewasa, di mana pada masa itu terjadi pertumbuhan yang pesat termasuk fungsi reproduksi sehingga mempengaruhi terjadinya perubahan-perubahan perkembangan fisik, mental, maupun peran sosial (Kumalasari Intan, 2012). Tujuan penelitian ini adalah untuk mengetahui gambaran pengetahuan remaja putri tentang perawatan Personal Higient di SMA Muhamadiyah Tahun 2019. Metodologi Penelitian Desain penelitian ini adalah deskriptif. Populasi dalam penelitian ini adalah siswi SMA Muhammadiyah kelas X yang berjumlah 271 orang. Dan sampel pada penelitian ini berjumlah 73 orang. Penelitian ini menggunakan teknik sampling Probablity sampling (Random Sampling). Hasil Penelitian Gambaran pengetahuan remaja putri tentang perawatan organ kewanitaan di SMA Muhammadiyah dalam kategori baik sebanyak 13 responden (17,8 persen). Gambaran pengetahuan remaja putri tentang perawatan organ kewanitaan di SMA Muhammadiyah dalam kategori cukup sebanyak 36 responden (49,3 persen). Gambaran pengetahuan remaja putri tentang perawatan Personal Higient di SMA Muhammadiyah dalam kategori kurang sebanyak 24 (32,9 persen). Kesimpulan Gambaran pengetahuan remaja putri tentang perawatan Personal Higient di SMA Muhammadiyah dalam kategori kurang sebanyak 24 (32,9 persen). Saran Diharapkan tenaga kesehatan lebih memperhatikan dalam pelayanan kesehatan dan meningkatkan pendidikan kesehatan atau konseling pada remaja putri tentang perawatan organ kewanitaan
\end{abstract}

Kata kunci: Personal Higient, Remaja, pengetahuan.

\begin{abstract}
According to Word Health Organitation (WHO), adolescence is a transition period from childhood to adulthood, during which period there is rapid growth including reproductive function so that it affects the changes in physical development, mental, and social roles (Kumalasari Intan, 2012). The purpose of this study was to determine the description of adolescent girls' knowledge about Personal Hygienic care in Muhamadiyah High School in 2019. Research Methodology The design of this study was descriptive. The population in this study were 271 class Muhammadiyah high school students. And the sample in this study amounted to 73 people. This study uses a sampling technique Probablity sampling (Random Sampling). Research Resultsv depictions of knowledge of young women about the care of female organs in SMA Muhammadiyah in the good category of 13 respondents (17.8 percent). Description of adolescent girls' knowledge about caring for female organs at Muhammadiyah High School in the sufficient category was 36 respondents (49.3 percent). The depiction of adolescent girls' knowledge about Personal Higient care in Muhammadiyah High School in the category of lacking as many as 24 (32.9 percent). Conclusion The description of the knowledge of young women about personal hygiene care in Muhammadiyah high schools in the category of lacking as many as 24 (32.9 percent). Suggestions It is expected that health workers pay more attention in health services and improve health education or counseling to young women about caring for female organs
\end{abstract}

Keyword: Personal Hygiene, Teenagers, knowledge 


\section{Pendahuluan}

Menurut Word Health Organitation (WHO),masa remaja merupakan masa peralihan dari masa anak-anak menuju dewasa, di mana pada masa itu terjadi pertumbuhan yang pesat termasuk fungsi reproduksi sehingga mempengaruhi terjadinya perubahan-perubahan perkembangan fisik, mental, maupun peran sosial (Kumalasari Intan, 2012).

Menurut Word Health Organitation (WHO), remaja adalah periode usia antara 10-19 tahun, sedangkan perserikatan bangsa-bangsa (PBB) menyebutkan kaum muda (youth) untuk usia antara 15-24 tahun. Sementara itu, menurut The Health Resources and Services Administrations Guidelines Amerika Serikat, rentan usia remaja adalah 11-21 tahun dan terbagi menjadi tiga tahap, yaitu remaja awal (11-14 tahun), remaja menengah (15-17 tahun), dan remaja akhir (18-21 tahun) (Kumiran, 2011).

Menurut Departemen Kesehatan Tahun 2014, di Indonesia jumlah remaja dan kaum muda berkembang sangat cepat. Jumlah remaja mencapai sekitar 65 juta jiwa atau 25 persen dari 255 juta jiwa jumlah penduduk Indonesia.

Dari hasil penelitian yang dilakukan di Amerika mengungkapkan lebih dari 20 juta perempuan Amerika menggunakan cairan pembersih kedalam vagina secara rutin. Sekitar 37\% perempuan Amerika yang berusia 15-44 tahun menggunakan cairan pembersih kedalam vagina secara teratur separuh dari perempuan yang menggunakan cairan pembersih kedalam vagina secara teratur seminggu sekali. Data penelitian tentang kesehatan reproduksi wanita menunjukkan 75\% wanita di Indonesia pernah menggunakan cairan pembersih dalam vagina yang telah menjadi bagian dari personal higienis mereka yang dilakukan secara rutin. Bahkan yang biasa digunakan adalah (51\%) adalah sabun dan (18\%) pembersih cair dengan berbagai merek (Septian, 2017).

Di Indonesia sekitar 74,9\% tingkat pengetahuan tentang kesehatan reproduksi masih kurang, bahkan menurut Survei di Jawa Tengah 68,6\% tingkat pengetahuan remaja putri tentang kesehatan reproduksi kurang (RISKESDAS, 2018).

Berdasarkan data survei Perkumpulan Keluarga Berencana Indonesia (PKBI) Jawa Tengah tahun 2018 pengetahuan remaja tentang cara-cara merawat organ reproduksi masih rendah karena minimnya pengetahuan atau informasi yang diperoleh sebesar $43,22 \%$ pengetahuan cukup $37,2 \%$ dan pengetahuan baik sebesar 19,50\% (Andriyani, 2017).

Hasil penelitian Sekar Alifia (2017) di MAN I Surakarta kelas XI menunjukkan bahwa pengetahuan remaja putri tentang vulva hygienesaat menstruasi dari 63 responden sebagian besar dalam kategori cukup terdapat 34 responden (54\%), baik terdapat 22 responden (34,9\%), dan kurang terdapat 7 responden $(11,1 \%)$. Berkaitan dengan remaja, kebersihan merupakan hal yang sangat penting dan harus diperhatikan karena kebersihan akan mempengaruhi kesehatan. kebersihan itu sendiri sangat dipengaruhi oleh nilai individu dan kebiasaan. Hal ini terjadi karena remaja sekarang ini menganggap masalah kebersihan adalah masalah yang tidak perlu di perhatikan, padahal jika masalah kebersihan dibiarkan terus menerus dapat mempengaruhi kesehatan secara umum (Tarwoto dan Wartonah, 2010).

Masalah kebersihan terjadi karena perilaku remaja putri kurang benar dalam menjaga kebersihan organ genetalianya. Padahal tinggal didaerah tropis yang panas membuat remaja sering berkeringat.Keringat ini meningkatkan kadar kelembaban tubuh, terutama pada organ seksual reproduksi yang tertutup dan berlipat. Dalam keadaan normal vagina mempunyai bau yang khas. Akibatnya bakteri mudah berkembang biak dan ekosistem divaginaterganggu, sehingga menimbulkanbau tidak sedapserta infeksi maka diperlukan perilaku yang baik untuk menjaga kebersihan dan keseimbangan ekosistem vagina (Ayu,2010). Untuk menjaga organ intim wanita agar selalu sehat dan juga terhindar dari berbagai macam penyakit kelamin maka hindarilah penggunaan sabun apapun diwilayah vagina dan hindari penggunaan cairan kimia pewangi (cairan yang khusus untuk membersihkan vagina). Karena hal tersebut dapat mengganggu keseimbangan flora dalam 
vagina. Jika terlalu sering menggunakannya, malah bisa membunuh bakteri baik yang terdapat di vagina. Efeknya justru akan menimbulkan tumbuhnya jamur, sehingga akan timbul gatal-gatal di daerah organ intim. Dan jangan pernah menyemprotkan minyak wangi ke dalam vagina (Septian, 2009).

Dari hasil studi pendahuluan pada tanggal 12 September 2019 di SMA Muhammadiyah dari 10 orang siswi didapatkan 3 orang dapat menjawab tentang pengertian pemakai cairan pembersih organ kewanitaan, mereka memakai dengan alasan ketidaknyamanan pada daerah kewanitaannya, mereka setiap hari memakai cairan pembersih organ kewanitaan, ada juga yang memakai pembersih vagina setelah menstruasi dan untuk mencegah keputihan. Mereka memakai pembersih dengan merek sabun sirih. Memulai memakai cairan pembersih vagina pada saat kelas 3 SMP dan 1 SMA. Sedangkan 7 orang belum begitu memahami tentang perawatan organ kewanitaan. Dari hasil wawancara tersebut dapat disimpulkan bahwa 10 orang yang telah diwawancarai ternyata lebih banyak yang belum mengetahui tentang perawatan organ kewanitaan. Berdasarkan latar belakang tersebut penulis tertarik untuk melakukan penelitian tentang "Tingkat Pengetahuan Remaja Tentang Personal Higient di SMA Muhamadiyah Tahun 2019".

\section{Metode}

Desain penelitian ini adalah deskriptif yaitu penelitian yang bertujuan menggambarkan secara sistematik dan akurat mengenai populasi atau mengenai bidang tertentu (Saifudin, 2011).

Populasi merupakan keseluruhan sumber data yang diperlukan dalam suatu penelitian. Penentuan sumber data dalam suatu penelitian sangat penting dan menentukan keakuratan hasil penelitian (Saryono, 2011). Populasi dalam penelitian ini adalah siswi SMA Muhammadiyah kelas X yang berjumlah 271 orang. Dan Sampel Penelitian Ini Berjumlah 73 Orang.

Teknik sampling adalah teknik pengambilan sampel (Sugiyono, 2013). Penelitian ini menggunakan teknik sampling Probablity sampling (Random Sampling), yaitu bahwa setiap subjek dalam populasi memiliki kesempatan yang sama untuk ikut serta sebagai sampel penelitian. Teknik sampel tersebut menggunakan teknik simple random sampling, yaitu semua individu berpeluang untuk diambil. Pada teknik acak sederhana, jumlah subjek dalam populasi terjangkau yang akan dipilih sampelnya dihitung terlebih dahulu (Saryono, 2011).

\section{Hasil dan Pembahasan}

Sampel dalam penelitian ini adalah siswi kelas X SMA Muhammadiyah yang berjumlah 73 siswi. Data pengetahuan remaja putri tentang perawatan organ kewanitaan. Dari tabel 1 Menunjukan indikator perawatan organ kewanitaan tentang pengertian pembersih vagina sebagian besar dengan tingkat pengetahuan baik yaitu sebanyak 33 responden $(45,2 \%)$, tujuan remaja putri merawat organ kewanitaan sebagian besar berpengetahuan kurang 36 responden $(49,3 \%)$, masalah yang timbul karena merawat organ kewanitaan dengan cara yang salah berpengetahuan cukup 45 responden $(61,6 \%)$, bahan dasar dari pembersih kewanitaan yang beredar sebagian responden berpengetahuan kurang 31 responden $(42,5 \%)$, anatomi genetalia eksterna dengan pengetahuan cukup yaitu sebanyak 28 responden $(38,4 \%)$, cara merawat organ intim yang baik dan benar dengan pengetahuan baik 28 responden $(38,4 \%)$. 
Tabel 1

Presentasi Gambaran Pengetahuan Tentang Perawatan Organ Kewanitaan (N=73)

\begin{tabular}{llcccccc}
\hline \multicolumn{1}{c}{ Pengetahuan } & \multicolumn{2}{c}{ Baik } & \multicolumn{2}{c}{ Cukup } & \multicolumn{2}{c}{ Kurang } \\
& F & \% & F & \% & F & \% \\
\hline pengertian pembersih organ kewanitaan & 33 & 45,2 & 23 & 31,5 & 17 & 23,3 \\
tujuan merawat organ kewanitaan & 19 & 26,0 & 18 & 24,7 & 36 & 49,3 \\
masalah yang timbul karena merawat & organ & 16 & 21,9 & 45 & 61,6 & 12 & 16,4 \\
kewanitaan dengan cara yang salah & 14 & 19,2 & 27 & 37,0 & 32 & 42,5 \\
bahan dasar dari pembersih vagina & 19 & 26,0 & 28 & 38,4 & 26 & 35,6 \\
anatomi genetalia eksterna & 28 & 38,4 & 19 & 26,0 & 26 & 35,6 \\
cara merawat organ intim yang baik dan benar & & & & &
\end{tabular}

Tabel 5.

Distribusi Responden Berdasarkan Tingkat Pengetahuan Siswi Tentang Perawatan Organ Kewanitaan (N=73)

\begin{tabular}{llcc}
\hline & Pengetahuan & N & Prosentase (\%) \\
\hline Baik & 13 & 17,8 \\
Cukup & 36 & 49,3 \\
Kurang & 24 & 32,9
\end{tabular}

Berdasarkan data yang diperoleh dari kuesioner dapat diketahui bahwa responden di kelas $\mathrm{X}$ SMA Muhammadiyah yang berjumlah 73 orang, lebih dari 49,3\% remaja putri mempunyai pengetahuan cukup tentang perawatan organ kewanitaan.

Gambaran pengetahuan remaja putri tentang perawatan organ kewanitaan di ukur dengan indikator pengertian pembersih vagina, tujuan remaja putri merawat organ kewanitaan, masalah yang timbul karena merawat organ kewanitaan dengan cara yang salah, bahan dasar dari pembersih vagina, anatomi genetalia eksterna, cara merawat organ intim yang baik dan benar. Untuk masing-masing indikator penilaian dengan hasil sebagai berikut :

Berdasarkan tabel 4. Hasil penelitian tentang presentasi gambaran pengetahuan tentang perawatan organ kewanitaan. Hasil penelitian didapatkan bahwa responden berpengetahuan baik tentang pengertian pembersih vagina. Responden tahu bahwa pembersih vagina adalah cairan yang digunakan dalam pembersih vagina. Hal tersebut sesuai dengan pernyataan dari teori Nara (2011), bahwa pembersih vagina adalah cairan yang di gunakan dalam proses pembersih vagina.

Pengetahuan responden tentang tujuan merawat organ kewanitaan dengan pembersih vagina, sebagian responden berpengetahuan kurang karena masih ada responden yang tidak mengetahui bahwa cairan pembersih vagina bisa dipakai untuk menghilangkan aroma tidak sedap dari daerah kewanitaan. Menurut Winarsih (2010), remaja putri menggunakan pembersih vagina bertujuan untuk membersihkan daerah kewanitaan, membilas darah setelah periode bulanan, menghilangkan aroma tidak sedap dari daerah kewanitaan, mengurangi keputihan.

Sebagian responden berpengetahuan cukup tentang masalah yang timbul karena merawat organ kewanitaan dengan cara yang salah. Sebagian responden mengetahui bahwa masalah yang ditimbulkan salah satunya adalah iritasi pada daerah kewanitaan. Hal ini sesuai dengan teori Kinarsih (2011), bahwa merawat organ kewanitaan dengan cara yang salah akan mengakibatkan iritasi pada daerah kewanitaan, infeksi yang disebabkan bakteri, penyakit radang panggul.

Sebagian responden berpengetahuan kurang tentang bahan dasar dari pembersih kewanitaan yang beredar. Karena masih ada reponden yang belum mengetahui bahwa povidone iodone merupakan 
salah satu bahan pembersih vagina. Menurut Fitria (2007), bahan dasar dari pembersih vagina yang beredar di masyarakat antara lain : daun sirih, povidone iodine, produk yang merupakan kombinasi laktoserum dan asam laktat.

Tentang anatomi genetalia eksterna, sebagian responden berpengetahuan cukup. Salah satunya responden mengetahui bahwa selaput darah (hymen) termasuk anatomi genetalia eksterna. Hal ini sesuai dengan teori menurut Manuaba (2012), ada beberapa bagian genetalia eksterna antara lain Mons Veneris, labia mayora, labia minora, klitoris, vulva, festibulum, hymen.

Sebagian responden berpengetahuan baik tentang cara merawat organ intim yang baik dan benar. Responden mengerti tentang cara merawat organ intim yang baik dan benar salah satunya tentang menghindari menggunakan celana dalam yang terlalu ketat karena menyebabkan daerah kewanitaan menjadi lembab.Ini sesuai dengan teori Livoti (2011), salah satunya yaitu untuk mempermudah penyerapan getah dan keringat, gunakanlah pakaian dalam yang berbahan katun, bukan nilon atau bahan sintetis lain yang memiliki daya serap yang rendah. Hindari menggunakan celana dalam yang terlalu ketat karena akan membuat kulit susah bernapas, sehingga daerah tersebut menjadi lembab.

Berdasarkan Tabel 5. Distribusi responden berdasarkan tingkat pengetahuan siswi tentang perawatan organ kewanitaan pada kelas X SMA Muhammadiyah. Dari hasil penelitian didapatkan bahwa 73 responden diperoleh hasil dalam kategori baik ada 13 responden (17,8 \%), sedangkan lainnya yang mempunyai pengetahuan cukup 36 responden $(49,3 \%)$ dan yang mempunyai pengetahuan kurang 24 responden $(32,9 \%)$.

Pada penelitian ini mayoritas hasil penelitian pengetahuan tentang perawatan organ kewanitaan adalah kategori cukup. Pengetahuan merupakan hasil dari tahu, dan ini terjadi setelah orang melakukan penginderaan terhadap suatu objek tertentu. Penginderaan terjadi melalui pancaindera manusia, yakni indera penglihatan, pendengaran, penciuman, rasa dan raba. Dalam penelitian ini sebagian besar pengetahuan responden tentang perawatn organ kewanitaan diperoleh dari teman, orang tua, guru, televisi, radio, koran atau majalah, petugas kesehatan dan internet (Fitriani, 2011).

Hal ini sesuai dengan pendapat Mubarok (2011), pengetahuan dipengaruhi oleh beberapa faktor yaitu faktor pendidikan, pekerjaan, umur, minat, pengalaman, kebudayaan lingkungan sekitar dan kemudahan mendapatkan informasi. Dalam penelitian ini responden mendapatkan informasi dari teman sebanyak 10 responden (14\%), orang tua 6 responden $(8 \%)$, guru 3 responden (4\%), televisi 17 responden ( $23 \%$ ), radio 1 responden $(1 \%)$, koran 4 responden $(6 \%)$, petugas kesehatan 3responden (4\%), internet 19 responden (26\%), lain-lain 10 responden (14\%). Dari kesimpulan diatas mayoritas responden mendapatkan informasi dari internet. Peneliti berasumsi dengan adanya kemudahan mendapatkan informasi tentang perawatan organ kewanitaan maka semakin luas juga pengetahuan yang didapat seseorang.

\section{Kesimpulan dan Saran}

Berdasarkan hasil penelitian yang dilakukan dapat diketahui bahwa Gambaran pengetahuan remaja putri tentang perawatan Personal Higient dalam kategori baik sebanyak 13 responden (17,8\%), Gambaran pengetahuan remaja putri tentang perawatan Personal Higient dalam kategori cukup sebanyak 36 responden (49,3\%). Gambaran pengetahuan remaja putri tentang perawatan Personal Higient dalam kategori kurang sebanyak 24 (32,9\%).

Diharapakan dengan adanya penelitian ini mahasiswa jauh lebih mampu melakukan perawatan personal hygiene dengan benar. 


\section{Daftar Pustaka}

Afifah, D. N., 2007, Faktor Yang Berperan Dalam Kegagalan Praktik Pemberian ASI Eksklusif, Studi Kuantitatif, Semarang.

Aprilia, Y., 2010, Analisis Sosialisasi Program Inisiani Menyusu Dini Dan ASI Eksklusif Kepada Bidan Di Kabupaten Klaten. Thesis.

Arikunto, S., 2014, Prosedur Penelitian : Suatu Pendekatan Praktik, PT Bumi Aksara, Jakarta.

Ario, R. P., 2015, Pengaruh Teknik Marmet Terhadap Produksi ASI Pada Ibu Post Partum 0-3 Hari, Vol.2(1), 16.

Astutik, R. Y., 2014, Payudara Dan Laktasi. Jakarta: Salemba Medika.

Basri, H., Amin, S., Umiyati, M., Mukhlis, H., \& Irviani, R. (2020). Learning Theory of Conditioning. Learning, 7(08), 2020.

Batubara, A., et al, 2017, The Effectiveness Of The Technique Of Secreting Breast Milk Production In PostPartum Women, Vol 1(3), 141-148.

Budiati, T., 2009, Efektifitas Pemberian Paket "Sukses ASI" Terhadap Produksi ASI Ibu Menyusui Dengan Seksio Sesarea di Wilayah Depok Jawa Barat, Thesis, Fakultas Ilmu Kesehatan Universitas Indonesia, Depok.

Cox, S., 2006, Breastfeeding With Confidence,Panduan Untuk Menyusui Dengan Kepercayaan Diri, PT Elex Media Komputindo, Jakarta, Hal. 20.

Depkes R.I., 2013, Riset Kesehatan Dasar (Riskesda) 2013, Badan Penelitian dan Pengembangan Kesehatan Kementrian Kesehatan, Jakarta.

Depkes R.I., 2015, Pusat Data dan Informasi (Pusdatin) 2015, Badan Penelitian dan Pengembangan Kesehatan Kementrian Kesehatan, Jakarta.

Dewi, V. N. L. \& Sunarsih, T., 2011, Asuhan kebidanan pada ibu nifas, Salemba Medika, Jakarta.

Dinas Kesehatan Provinsi Lampung, 2017,Profil Kesehatan Ibu dan Anak Provinsi Lampung tahun 2016,Dinas Kesehatan Provinsi Lampung. Bandar Lampung.

Dinas Kesehatan Kabupaten Lampung Utara, 2017,Profil Kesehatan Ibu dan Anak Kabupaten Lampung Utara 2016,Dinas Kesehatan Kabupaten Lampung Utara, Lampung Utara.

Hidayat, A. A. A., 2011, Metode Penelitian Keperawatan Dan Teknik Analisis Data, Salemba Medika, Jakarta.

Hisni, D, Widowati, R, dan Kurniati, D, 2018, Buku Panduan Skripsi Fakultas Ilmu Kesehatan, Fakultas Ilmu Kesehatan Universitas Nasional, Jakarta.

Icesmi, 2013. Kehamilan persalinan nifas. Nuha Medika,Yogyakarta.

IDAI, 2013,ASI Sebagai Pencegah Malnutrisi pada Bayi, http:/www,idai,or,id/artikel/klinik/asi/asi-sebagaipencegah-malnutrisi-pada-bayi, diakses 24 Mei 2018.

Jannah, N., 2011, Asuhan Kebidanan Ibu Nifas, Ar-Ruzz Media, Yogyakarta.

Khaatoon, S., etal., 2012, Expression of Breast Milk-an Update, Review Article, 4(2), 62-64.

Kementerian Kesehatan R.I., 2016, Profil Kesehatan Indonesia 2016, Kementerian Kesehatan, Jakarta. 
Kumalasari, D., Kameliawati, F., Mukhlis, H., \& Kristanti, D. A. (2019). Pola Menstruasi dengan Kejadian Anemia pada Remaja. Wellness And Healthy Magazine, 1(2), 187-192.

La Leche Leagua International, 2003, Manual Expression Of Breast Milk Marmet Tecnique,http://llrochester.weebly.com/uploads /79/5/4/795404/marmet tecnique tearoff.pdf. Diakses pada tanggal 30 Maret 2018.

Maritalia, D., 2012, Asuhan Kebidanan Nifas dan menyusui, Pustaka Pelajar, Yogyakarta.

Marmi, 2012, Asuhan Kebidanan Pada Masa Nifas "Peuperium Care", Yogyakarta : Pustaka Pelajar.

Mochtar, R, 2011, Sinopsis Obsetri. Jakarta: EGC.

Mukhlis, H., Kristianingsih, A., Fitrianti, F., Pribadi, T., Kumalasari, D., Febriyanti, H., \& Maseleno, A. (2020). The effect of expressive writing technique to stress level decrease of new student at AlFalah Putri Islamic Boarding School, Margodadi, Tanggamus. Annals of Tropical Medicine and Health, 23, 192-200.

Notoatmodjo, S., 2010, Metodologipenelitiankesehatan. Jakarta: Rineka Cipta.

Nur, M., \& Mukhlis, H. (2020). Kualitas hidup ditinjau dari pengetahuan keluarga tentang perawatan lansia. Indonesia Berdaya, 1(1), 15-22.

Purwanti, E., 2012, Asuhan Kebidanan Untuk Ibu Nifas, Cakrawala Ilmu, Yogyakarta

Rahayu, R., \& Andriyani, A., 2014, Metode Memperbanyak Produksi ASI Pada Ibu Post Sectio Caesarea Dengan Teknik Marmet Dan Breast Care Di RSUD Karanganyar. Vol 9 (2), 56-68.

Rahayu, Y. P., et al, 2012, Buku Ajar Masa Nifas Dan Menyusu, Mitra Wacana Medika, Jakarta.

Republik Indonesia, Peraturan Daerah Provinsi Lampung Nomor 17 Tahun 2014 Tentang Air Susu Ibu Eksklusif.

Risnawati, I. \& Tristanti, I., 2018, Efek Teknik Marmet Terhadap Produksi Air Susu Ibu Nifas, Vol 9 (1), 27-34.

Roesli, U., 2012, Panduan Konseling Menyusui, Pustaka Bunda Grub Puspa Swara, Jakarta.

Rukiyah, A. Y., et. al., 2011, Asuhan Kebidanan III (Nifas), TIM, Jakarta.

Saleha, S., 2009, Asuhan kebidanan pada masa nifas, Salemba Medika, Jakarta.

Saputra, Y., 2016, Pekan ASI Sedunia: Angka Pemberian ASI Di Indonesia Masih Rendah, https:/www.rappler.com/indonesia/142238-pekan-asi-sedunia-indonesia-masih-rendah diakses : 15 Maret 2018.

Sastroasmoro, S. \& Ismael, S., 2008, Dasar-dasar Metodologi Penelitian Klinis, Edisi ke-3, Sagung Seto, Jakarta.

Setiawandari, 2014, Perbedaan Pengaruh Teknik Marmet Dan Pijat Oksitosin Terhadap Produksi ASI Pada Ibu Post Partum Di Rumah Sakit Ibu Dan Anak IBI Surabaya, Thesis, Program Pascasarjana Universitas Sebelas Maret Surakarta.

Sugiono, 2009, Metode Penelitian Kuantitatif, Kualitatif dan RED, Alfabeta, Bandung.

Unicef Indonesia, 2013, ASI Adalah Penyelamat Hidup Paling Murah Dan Efektif Di Dunia,http://www.unicef.org/indonesia/dd/media 21270.html, Diakses pada tanggal 15 Maret 2018.

Utami, A. P., 2009, Hubungan Inisiasi Menyusu Dini Dengan Kecepatan Pengeluaran ASI Pada Ibu Post Partum Di BPS Firda Tuban, KTI, Prodi DIII Kebidanan STIKES NU Nuban. 
Widiastutik, A., et. al., 2015, Effect of Marmet Technique on Smoothhness of Breastfeeding and Baby Weigh Gain, Jurnal kesehatan masyarakat nasional Vol. 9(4), 315-319.

Wijaya, P. W. D., 2018, Faktor-Faktor Yang Berepengaruh Terhadap Perilaku Pemberian ASI Eksklusif, Publikasi Ilmiah, Program Studi Pendidikan Dokter Fakultas Kedokteran Universitas Muhammadiyah Surakarta. 